\title{
OHLÁŠENÍ BRZKÉHO UZAVŘENÍ DOHODY O VĚČNÉM MÍRU VE FILOSOFII
}

\author{
Immanuel Kant
}

\section{První oddíl \\ Radostný výhled na blízký věčný mír ve filosofii}

\section{Od nejnižšího stupně lidské přirozenosti}

k jejímu nejvyššímu stupni, $\mathrm{k}$ filosofii

[413] Stoik Chrysippos to vyjadřuje působivě: „Příroda dala vepři duši místo soli, aby neshnil.“2 Tot' nejnižší stupeň přirozenosti člověka před veškerou kulturou, totiž čistě zviŕecí instinkt. - Jako by zde ale filosof jasnozřivě nahlédl do fyziologických systémů naší doby; jenže my dnes místo slova „dušse“ raději užíváme termínu „životní síla“ (a činíme to právem, protože z účinku lze přece dobře usuzovat na sílu, která jej způsobuje, ale ne hned na nějakou substanci, která by k takovému účinku byla zvlášt' uzpůsobena), život se však nyní klade

1 I. Kant, Verkündigung des nahen Abschlusses eines Tractats zum ewigen Frieden in der Philosophie, in: Kants Gesammelte Schriften, vyd. Königlich Preußische Akademie der Wissenschaften (=AA), Berlin 1923, VIII, str. 413-422 (paginace akademického vydání je v překladu vyznačena $\mathrm{v}$ hranatých závorkách), původně otištěno in: Berlinische Monatsschrift, 28, 1796, str. 485-504. Jde o Kantovu reakci na text právníka a spisovatele J. G. Schlossera Schreiben an einen jungen Mann, der die kritische Philosophie studieren wollte (Dopis mladému muži, který by chtěl studovat kritickou filosofii, 1796), v němž autor reaguje na výtky, které mu Kant adresoval v článku Von einem neuerdings erhobenen vornehmen Ton in der Philosophie (1796) (in: AA VIII, str. 387-426, český překlad: I. Kant, O povýšeném tónu, jenž nově zaznívá ve filosofii, přel. T. Koblížek, in: Reflexe, 43, 2012, str. 101-115, ke kontextu diskuse mezi Kantem a Schlosserem viz též: T. Koblížek, Kantův text o povýšeném tónu ve filosofii, in: tamt., str. 116-118). Schlosser následně publikuje Zweites Schreiben an einen jungen Mann, der die kritische Philosophie studieren wollte, veranlaßt durch den angehängten Aufsatz des Herrn Professor Kant über den Philosophen-Frieden (Druhý dopis mladému muži, který by chtěl studovat kritickou filosofii, podnícený přiloženým článkem pana profesora Kanta o míru ve filosofii), na který Kant již nereaguje. - Pozn. překl.

2 Cicero, O přirozenosti bohů, přel. A. Kolář, Praha 1948, str. 121, překlad upraven. 
do působení stimulujících sil (životního stimulu) a schopnosti na stimulující síly zpětně působit (životní schopnosti) a zdravým se nazývá takový člověk, ve kterém odpovídající stimul nevyvolá ani nadměrnou, ani př́liš slabou reakci; v opačném případě přecházejí animální operace přírody v operace chemické, které mají za následek zahnívání a rozklad, takže rozklad nemusí (jak se dříve věřilo) nastat $\mathrm{v}$ důsledku smrti a po smrti, nýbrž smrt může nastat $\mathrm{v}$ důsledku předcházejícího rozkladu. - Zde je však přirozenost $\mathrm{v}$ člověku představena ještě před jeho lidskostí, a tedy ve své všeobecnosti, jak je činná ve zviřreti, jen aby rozvinula síly, které potom člověk může užívat podle zákonů svobody; tato činnost a její podněcování ale ještě nejsou praktické, nýbrž pouze mechanické.

\section{A. \\ O fyzických příčinách filosofie v člověku}

[141] Odhlédneme-li od vlastnosti sebevědomí, která člověka odlišuje od všech ostatních zvir̃at a díky které je člověk živočich rozumný (jemuž může být díky jednotě vědomí dána pouze jedna duše), pak musí být sklon tuto schopnost užívat k rozumování, rozumovat dále metodicky a pouze prostřednictvím pojmů, tj. filosofovat; vystupovat následně se svou filosofií polemicky proti druhým, tj. disputovat, a - protože se to málokdy obejde bez afektu - hádat se o ni, a nakonec spolu ve zbrani (škola proti škole, muž proti muži) otevřeně válčit; - tento sklon, tvrdím, nebo spíše nutkání musí být nahlíženo jako jedno z laskavých a blahodárných opatření přírody, kterým se od člověka snaží odvrátit to velké neštěstí, jímž je hnilobné odumírání živého těla.

\section{O fyzickém účinku filosofie}

Účinkem filosofie je zdraví (status salubritatis) rozumu. - Protože je ale lidské zdraví (podle toho, co bylo řečeno výše) neustálým propukáním nemoci a opětovným uzdravováním, k zachování rovnováhy, která se nazývá zdravím a visí na vlásku, nestačí pouze dieta praktického rozumu (něco jako jeho gymnastika), nýbrž k tomu musí (terapeuticky) působit filosofie jakožto lék (materia medica), k jehož užívání je pak zapotřebí zdravotníků a lékařů (pouze ti druzí jsou přitom oprávněni toto užívání predepisovat), přičemž policie musí hlídat, aby se v tom, jakou filosofii 
má kdo studovat, odvažovali radit pouze kvalifikovaní lékaři, nikoli amatérí fušující do řemesla, o jehož principech nemají ponětí.

Př́klad účinnosti filosofie coby léčebného prostředku podal stoický filosof Poseidónios ${ }^{3}$ a to prostřednictvím experimentu, který v př́itomnosti velkého Pompeia vykonal na své vlastní osobě: během ostré polemiky s epikurejskou školou přemohl prý totiž prudký záchvat dny, nechal ji sestoupit do nohou [415] a zabránil jí dospět k srdci a hlavě, čímž podal důkaz o bezprostředním fyzickém účinku filosofie, který jejím prostřednictvím příroda zamýšlela (tělesné zdraví), zatímco obhajoval tezi, že bolest není zlem. ${ }^{4}$

\section{O zdánlivé neslučitelnosti filosofie}

se stavem jejího trvalého míru

Dogmatismus (např. Wolffovy školy) je polštář k usínání a konec všeho probouzení, které je přitom vlastním dobrodiním filosofie. - Skepticismus, který, je-li doveden do konce, tvoří pravý opak dogmatismu, nemá nic, čím by mohl činnost rozumu dále podněcovat, jelikož vše odkládá nevyužité stranou. - Moderantismus, který směřuje k prostřednosti a který je toho mínění, že nalezl kámen mudrců v subjektivní pravděpodobnosti, a domnívá se, že nedostatek dostatečného důvodu lze nahradit nakupením mnoha izolovaných důvodů (z nichž žádný není sám o sobě průkazný), není filosofií vůbec; s tímto léčebným prostředkem (doxologií) se to má stejně jako s morovými kapkami či benátským theriakem: pro všechno to dobro, kvůli kterému se k nim sahá zleva zprava, nejsou nakonec dobré $\mathrm{k}$ ničemu.

3 Cicero, Tuskulské hovory, přel. V. Bahník, Praha 1976, str. 116-117.

4 V latině lze dvojznačnosti ve výrazech „zlé“ (malum) a „špatné“ (pravum) předejít snáze než v řečtině. - Vzhledem ke zdraví a nemoci (bolesti) je člověk podřízen zákonu přírody a je pouze pasivní (jako všechny smyslové by tosti); vzhledem ke špatnosti (a dobru) je podřízen zákonu svobody. Prvé zahrnuje to, co člověk trpí, druhé zahrnuje to, co dobrovolně činí. - Vzhledem k osudu je rozdíl mezi pravým a levým (fato vel dextro vel sinistro) pouze rozdílem ve vnějším vztahu člověka. Vzhledem $\mathrm{k}$ jeho svobodě a vztahu zákona $\mathrm{k}$ jeho sklonům jde ale o rozdíl uvnitř člověka. - V prvním případě se klade rovné proti šikmému (rectum obliquo), ve druhém rovné proti křivému, zmrzačenému (rectum pravo sive varo, obtorto).

Tedy pokud latiník klade nešt’astnou událost na levou stranu, vychází to zřejmě z toho, že proti př́padnému útoku se nelze tak obratně bránit levou jako pravou rukou.Že ale u augurů, když věštec obrátil svůj pohled k tzv. chrámu (na jihu), vydával blesk, který přišel zleva, za št’astné znamení, má patrně ten důvod, že bůh hromu, který pomyslně stál proti věštci, drží blesk naopak v pravé ruce. 


\section{O skutečné slučitelnosti kritické filosofie se stavem jejího trvalého míru}

[416] Kritická je taková filosofie, která nezačíná pokusy budovat či bořit systémy ani úsilím (jako moderantismus) stavět na podpěrách střechu bez domu k prŕíležitostnému noclehu, nýbrž zkoumáním schopnosti lidského rozumu (at' už s jakýmkoliv záměrem), a která tedy nerozumuje do větru, pokud je řeč o filosofématech, jež nelze doložit žádnou možnou zkušeností. - A přece v lidském rozumu existuje něco, co nám nemůže být známo prostřednictvím zkušenosti a co přesto dokazuje svoji skutečnost a pravdivost v účincích, které mohou být znázorněny ve zkušenosti, a proto také (a sice podle principu a priori) prostě přikázány. Je to pojem svobody a z něj pocházející zákon kategorického, tj. bezpodmínečně přikazujícího imperativu. - Prostřednictvím tohoto zákona získávají ideje, které by pro čistě spekulativní rozum byly zcela prázdné, i když právě on nás k nim jako základům poznání našeho posledního účelu nevyhnutelně odkazuje, určitou, byt' pouze morálně-praktickou realitu: totiž jednat tak, jako by jejich předměty (Bůh a nesmrtelnost), které smíme tudíž v onom (praktickém) ohledu postulovat, byly dány.

Tato filosofie, která je (vůči těm, kteří mylně zaměňují jevy za věci o sobě) vždy ozbrojeným a právě proto činnost rozumu neustále doprovodným stavem otevírá výhled na věčný mír mezi filosofy jednak díky bezmoci protikladných teoretických důkazů, jednak díky síle praktických důvodů k přijetí jejích principů; - na mír, který mj. má navíc tu výhodu, že síly subjektu, který se v důsledku útoků ocitl ve zdánlivém nebezpečí, udržuje v neustálé pohotovosti a tím také podporuje záměr prrírody jej prostřednictvím filosofie stále probouzet k životu a odvracet od něho smrtelný spánek.

Pokud se na věc díváme z tohoto hlediska, je třeba výrok onoho muže, který nevyniká jen ve svém vlastním (matematickém) oboru, [417] ale také v mnoha dalších, muže korunovaného činorodým, stále ještě plodným stářím, interpretovat ne jako nešt'astnou, ale jako št'astnou zprávu, pokud filosofům zcela upírá bezstarostný klid a mír spočívající na domnělých vavřínech. ${ }^{5}$ Takový mír by totiž vedl jen k ochabnutí sil a maření účelu př́rody, pokud jde o filosofii coby prostředek, jenž

5 Když moudrým slovem čin svůj řídí / opouští lidé boj a svár; / pak všichni spolu v míru žijí, / jen filosof se bije dál. Kästner. 
nás má neustále pobízet k poslednímu účelu lidstva; naproti tomu bojová pohotovost ještě není válka, nýbrž může a má jí spíše zabránit, a tedy zajistit mír, a to rozhodující převahou praktických důvodů nad protidůvody.

B.

Hyperfyzické základy lidského života

za účelem jeho filosofie

Prostřednictvím rozumu je lidské duši přidán duch (mens, vov̂ऽ), aby člověk nevedl jen život, který odpovídá mechanismu přírody a jejím technicko-praktickým zákonům, ale také život, který odpovídá spontaneitě svobody a jejím morálně-praktickým zákonům. Tento životní princip se nezakládá na pojmech něčeho smyslového, které ve svém souhrnu především (přede vším praktickým užíváním rozumu) předpokládají vědu, tj. teoretické poznání, nýbrž vychází nejprve a bezprostředně z ideje nadsmyslového, totiž svobody, a morálního kategorického imperativu, který nám ji teprve činí zjevnou; a tak zakládá filosofii, jejíž nauka není pouze (jako matematika) dobrým instrumentem (nástrojem k libovolnému účelu), tzn. pouhým prostředkem, nýbrž kterou je samo o sobě povinností učinit zásadou svého života.

Co je filosofie jako nauka, která je mezi všemi ostatními vědami největší potřebou člověka?

Je tím, co naznačuje už její název: hledáním moudrosti. [418] Moudrost je ale souladem vůle a posledního účelu (nejvyššího dobra); a protože ten, nakolik je dosažitelný, je také povinností, a naopak, pokud je povinností, musí být také dosažitelný, a takový zákon jednání se nazývá morální, pak lidská moudrost nebude nic jiného než vnitřní princip vůle dodržovat morální zákon, at' už je její předmět jakýkoliv; ten bude ale vždy nadsmyslový, protože vůle určená empirickým předmětem může sice zakládat technicko-praktické dodržování pravidla, nikoli však povinnost (která není fyzickým vztahem). 


\section{O nadsmyslových předmětech našeho poznání}

Jsou jimi Bůh, svoboda a nesmrtelnost. - 1) Bůh jako absolutně zavazující bytost; 2) svoboda jako schopnost člověka prosazovat plnění svých povinností (coby Božích příkazů) navzdory veškeré moci př́rody; 3) nesmrtelnost jako stav, v němž má být člověku dán podíl na blahu či utrpení v závislosti na jeho morální hodnotě. - Jak vidno, nacházejí se tyto předměty ve vztahu podobném řetězci tří vět atributivního sylogismu; a jelikož jim, právě proto, že jsou to ideje nadsmyslového, nemůže být v teoretickém ohledu dána žádná objektivní realita, bude jim moci náležet, pokud jim však vůbec má být zjednána, jen v praktickém ohledu coby postulátům morálně-praktického rozumu. ${ }^{6}$

Prostřední z těchto idejí, totiž idea svobody, protože existence svobody je obsažena v kategorickém imperativu, který neponechává prostor žádné pochybnosti, je tudíž s těmi dvěma zbylými logicky spojena; proto kategorický imperativ, nejvyšší princip moudrosti, předpokládající tedy také poslední účel nejdokonalejší vůle (nejvyšší blaženost, jež je v souladu s moralitou), zahrnuje pouze podmínky, [419] za nichž lze tomuto účelu jedině učinit za dost. Nebot' jedinou bytostí, která je s to vykonat odpovídající rozdělení, je Bůh; a jediný stav, v němž může být tento výkon proveden na rozumných světských bytostech a $\mathrm{v}$ plné shodě $\mathrm{s}$ oním konečným účelem, je předpoklad přetrvání života, jež je založeno v jejich přirozenosti, tj. nesmrtelnost. Nebot' kdyby přetrvání života nebylo založeno $\mathrm{v}$ jejich přirozenosti, znamenalo by pouze naději budoucího života, ne však takového, který musí rozum nutně (v důsledku morálního imperativu) předpokládat.

\section{Závěr}

Je tedy pouhým nedorozuměním či záměnou morálně-praktických principů mravnosti za principy teoretické, z nichž pouze ty první mohou zjednat poznání nadsmyslového, pokud ještě dojde ke sporu o to, co říká

6 Postulát je a priori daný praktický imperativ, jehož možnost nelze nijak vysvětlit (a tedy ani dokázat). Nepostulujeme tedy věci, nebo dokonce existenci nějakého předmětu, nýbrž postulujeme pouze maximu (pravidlo) jednání subjektu. - Pokud je tedy povinností usilovat o určitý účel (nejvyšší dobro), musím být také oprávněn předpokládat, že zde existují podmínky, za nichž jedině je tento výkon povinnosti možný, třebaže ty jsou nadsmyslové a my nejsme s to (v teoretickém ohledu) dospět k jejich poznání. 
filosofie jako nauka o moudrosti; z jejího stanoviska, protože proti ní již není a nemůže být namítáno nic vážného, lze důvodně

ohlásit brzké uzavření dohody o věčném míru ve filosofii.

\section{Druhý oddíl}

\section{Znepokojivý výhled na blízký mír ve filosofii}

Pan Schlosser, muž velkého literárního nadání a (jak máme důvod se domnívat) podpoře dobra nakloněného způsobu myšlení, aby si ve volné, nikoli však zahálčivé chvíli odpočinul od donucující, autoritě podléhající správy zákona, nečekaně vstupuje na bitevní pole metafyziky, kde spor bývá daleko trpčí než v oboru, který právě opustil. - Kritická filosofie, o které se domnívá, že ji zná, ačkoli nahlédl jen poslední závěry, jež z ní vyplývají, a kterou nutně musel pochopit nesprávně, protože kroky, jež k ní vedou, neprošel se svědomitou pílí, ho pobouřila; a tak se honem stal učitelem „mladého muže, který by (jak říká) chtěl studovat kritickou filosofii“", aby jej od toho odradil, aniž se ovšem před tím sám poučil.

[420] Jde mu jen o to, aby kritiku čistého rozumu pokud možno odklidil z cesty. Jeho rada se podobá onomu ujišt'ování, které dávali dobří přátelé ovcím: kéž by se jim jen chtělo zbavit psů, aby spolu žili v trvalém míru jako bratři. - Pokud žák uposlechne této rady, stává se hračkou v rukou učitele, který chce „upevnit jeho vkus (jak říká) prostřednictvím starověkých autorů (v umění přemlouvat, prostřednictvím subjektivních důvodů $\mathrm{k}$ souhlasu, místo metody přesvědčování, prostřednictvím objektivních důvodů)“. Pak si je učitel jist: žák si nechá podstrčit zdání pravdy (verisimilitudo) namísto pravděpodobnosti (probabilitas) a pravděpodobnost v soudech, které vůbec mohou vycházet pouze a priori z rozumu, namísto jistoty. „Neuhlazená, barbarská řeč kritické filosofie“ se mu nebude líbit; přestože jako barbarské musí být spatřováno spîše to, je-li do elementární filosofie zaváděno krasodušné výrazivo. - Naříká si nad tím, že „,všem tušením, výhledům k nadsmyslovému, každému géniu básnictví mají být přistřižena křídla“" (pokud to filosofii přísluší!).

Filosofie se v té části, která zahrnuje nauku o vědění (v části teoretické) a kterou naprosto nelze opomenout, přestože se zaměřuje především na omezování nepřiměřených nároků teoretického poznání, vidí ve své praktické části nucena vrátit k metafyzice (mravů) coby souhrnu čistě formálních principů pojmu svobody, ještě než se klade otázka po účelu 
jednání (matérii vůle). - Náš antikritický filosof tuto úroveň přeskakuje, nebo ji spíše podceňuje natolik, že zásadu „Jednej podle maximy, o které můžeš zároveň chtít, aby se stala všeobecným zákonem! ", která může sloužit za prubírrský kámen jakéhokoliv oprávnění, chápe zcela chybně a dává jí význam, který ji omezuje na empirické podmínky, a tím ji činí nezpůsobilou k tomu, aby byla kánonem čistého morálně-praktického rozumu (kterému se přesto nějaký kánon dát musí); vrhá se tak na docela jiné pole, než kam jej onen kánon odkazuje, a vyvozuje nesmyslné důsledky.

Je ale zřejmé, že zde není řeč o principu užívání prostř̌edků k nějakému určitému účelu (nebot' potom by to byl pragmatický, [421] nikoli morální princip); že neklamným znakem morální nemožnosti jednání není to, když maxima mé vůle, učiněna všeobecným zákonem, odporuje maximě vůle druhého, nýbrž to, když odporuje sama sobě (což mohu posoudit podle principu sporu, z pouhých pojmů, a priori, zcela nezávisle na zkušenosti, např. ,zda do své maximy zahrnu rovnost jmění nebo vlastnictví“). - Pouze neznalost, nebo snad něco horšího, totiž sklon k šikaně mohly podnítit tento útok, který však

\section{vyhlášení věčného míru ve filosofii}

nemůže překazit. Nebot' mírové spojenectví, které má tu povahu, že je (bez kapitulace) uzavřeno ihned, jakmile si jednotlivé strany navzájem porozumí, může být také vyhlášeno za uzavřené, nebo přinejmenším za blízké uzavření.

I když je filosofie představena pouze jako nauka o moudrosti (což je také její vlastní význam), nelze ji přesto obejít ani jako nauku o vědění, nakolik toto (teoretické) poznání zahrnuje elementární pojmy, kterých užívá čistý rozum; za předpokladu, že se tak děje jen proto, aby se rozumu postavili před oči jeho meze. Sotva tedy může být otázkou filosofie v prvním významu to, zda má člověk svobodně a otevřeně přiznat, co a odkud ve skutečnosti o svém předmětu (smyslovém a nadsmyslovém) opravdu ví, nebo co jen v praktickém ohledu (protože jeho předpoklad je prospěšný poslednímu účelu rozumu) předpokládá.

Může být, že pravdivé není vše, co člověk za takové pokládá (nebot' se může mýlit); ale ve všem, co říká, musí být pravdomluvný (nesmí klamat): je dále možné, že jeho vyznání je pouze vnitřní (před Bohem), 
nebo také vnější. - Porušení této povinnosti být pravdomluvný znamená lež; z toho důvodu může existovat vnější, ale také vnitřní lež, takže obě spolu mohou být ve shodě, ale také si navzájem odporovat.

Lež, at' už je vnitřní či vnější, je dvojího druhu: 1) když člověk vydává za pravdivé něco, o čem si je vědom, [422] že je to nepravdivé, 2) když vydává za jisté něco, o čem je si vědom, že je to subjektivně nejisté.

Lež („od otce lží, skrze něhož vešlo do světa veškeré zlo“) ${ }^{7}$ je hnilobnou skvrnou na lidské přirozenosti; a přesto je tón pravdomluvnosti (po vzoru některých čínských obchodníků, kteří si nad své krámky věší zlatě vysázený nápis: „Zde se nepodvádí“), zejména co se týče toho, co je nadsmyslové, tónem obvyklým. - Př́kaz „Nelži!“ (i kdyby to bylo v tom nejzbožnějším úmyslu), co nejniterněji přijatý za zásadu filosofie jakožto nauky o moudrosti, by sám mohl nejen způsobit, ale také jednou provždy zajistit ve filosofii věčný mír. ${ }^{8}$

Přeložil Robin Pech

$7 \quad$ Srv. $J 8,44 ; \check{R} 5,12$. - Pozn. překl.

8 Překlad vznikl v rámci zastř̌ešujícího projektu „Krize racionality a moderní myšlení“, projektu „Politická a rétorická dimenze Kantovy kritické filosofie“ řešeného na Filozofické fakultě Univerzity Karlovy z prostředků Specifického vysokoškolského výzkumu na rok 2018. Za pomoc s překladem děkuji Jindřichu Karáskovi, Radomíru Rozbrojovi, Martinovi Pokornému (jenž je autorem překladu Kantem citovaných veršů A. G. Kästnera) a Tomáši Koblížkovi. - Pozn. překl. 